Article

\title{
Tourism Stakeholder Perspective for Disaster-Management Process and Resilience: The Case of the 2018 Hokkaido Eastern Iburi Earthquake in Japan
}

\author{
Chung-Shing Chan ${ }^{1, * \mathbb{C}}$, Kazuo Nozu ${ }^{2}$ and Qinrou Zhou ${ }^{3}$ \\ 1 Department of Geography and Resource Management, The Chinese University of Hong Kong, \\ Sha Tin, N.T., Hong Kong \\ 2 Liberal Arts Education Center, Kumamoto Campus, Tokai University, 9-1-1 Toroku, Higashi-ku, \\ Kumamoto-shi, Kumamoto 862-8652, Japan; nozukazuo@tokai-u.jp \\ 3 School of Public Administration, University of Electronic Science and Technology of China, \\ Chengdu 611731, China; zhouqinrou@std.uestc.edu.cn \\ * Correspondence: ccs_johnson@cuhk.edu.hk; Tel.: +852-3943-6233
}

Received: 19 August 2020; Accepted: 19 September 2020; Published: 23 September 2020

check for updates

\begin{abstract}
The 2018 Eastern Iburi Hokkaido earthquake in Japan caused infrastructural damage and tourism disruption within a natural-hazard-prone country. This research advances the theoretical foundation and development of natural disaster management through a series of in-depth interviews with the local tourism stakeholders on the investigation of how the role of tourism across the pre-to-post earthquake period is considered by the stakeholders. These local tourism stakeholders have performed or expected a range of actions related to the disaster-management process and contributed to destination resilience. The qualitative analysis discovers, firstly, the multi-functionality of tourism resources, spaces, and industries for disaster preparation; secondly, the evacuation and emergency arrangements during the prodromal and emergency phases; and moreover, more possibilities of restoring the affected destination to a state of long-term (re)development during the post-disaster phases. Information and communication barriers are the major difficulties to be tackled for disaster preparedness. Product creation, image improvement, local knowledge enrichment, and, more importantly, people-to-people and people-to-place connections all contribute to the result of sustainable tourism development. From the destination resilience perspective, collaboration is the key determinant of an improved Hokkaido region. This factor could integrate stakeholders through shared local values, experiences, and memories of disaster risk communication and strategies for preparedness.
\end{abstract}

Keywords: destination recovery; destination resilience; disaster management; multi-stakeholder perspective; organizational culture; sustainable tourism

\section{Introduction: The Relationship between Natural Disasters and Tourism}

A natural disaster refers to any natural event, which could be sudden or progressive, causing hazardous impacts on the affected area in which the local communities must take exceptional measures in response to cope with the event [1,2]. Earthquakes are a frequent form of natural disasters in many countries [3-5]; Japan is one of the most distressed countries from earthquakes and related disasters, such as the massive 2011 Tōhoku earthquake and tsunami [6]. With continuous development in tourism activities, academic studies have focused much attention on the tourism industries and destinations that have countered these large-scale natural disasters [7]. Only until a recent global analysis, the effects 
of natural and man-made disasters on the international tourist flow were evaluated with statistics [8]. Tourism researchers have focused on specific knowledge areas with respect to different aspects of destination-disaster connection such as risk assessment for industries and businesses [9], risk reduction through emergency management and public-private collaboration [10,11], impact assessment and mitigation [7,12-14], and impact on regional tourism [15].

Compared with other engineering-related disciplines, public management, and geophysical sciences, the study of tourism has still received smaller coverage in disaster-related research in recent decades $[4,16]$. Many earlier studies were largely destination-oriented and focused on how tourism industries could recover from natural disasters $[6,17,18]$, however, they tend to give lesser attention to the overall contribution of tourism to disaster recovery and management [19]. The recent global outbreak of coronavirus has clearly shown how a globalized world has reciprocally led to the spread of disease and, at the same time, been detached by the cease of travel and mobility during the pandemic period as both a kind of natural and man-made disaster [20-22].

Based on the early theoretical base of disaster research in the 1990s [23,24], Faulkner [25] and Ritchie [26] developed two disaster-management frameworks that have advanced the theoretical foundation of tourism and disaster connection across pre-event, prodromal, emergency, intermediate, long-term recovery, and resolution phases. These two frameworks were further adopted by many researchers in subsequent studies, which supported a holistic tourism-specific disaster-management model or "lifecycle" (e.g., by [27-29]), a multi-dimensional disaster impact assessment [14], the analysis of micro-level statistics in tourism recovery [17], and the use of indicators for post-crisis sustainable tourism development [30].

Due to the varied nature of natural disasters and destination conditions, scholars have developed a pool of studies on how destinations and the tourism industry performed across the multiple phases of disasters [31]. These studies provided knowledge regarding different aspects of prevention and preparation $[9,10,27,32,33]$, as well as the risk perceptions and strategies for risk reduction $[34,35]$. There was relatively weaker empirical attention to examine destinations from a more holistic perspective [19], although the connection between preparedness and recovery was clear [36]. Tourism scholars also called for increasing the understanding of tourism industries in response to natural disasters [16]. It is essential to look forward to more research on tourism recovery and sustainability [37], although researchers were more likely to relate sustainability with post-disaster marketing opportunities and demand recovery [38-43], rather than integrating tourism-based contributions to natural disaster management.

\section{Literature Review}

\subsection{Natural Disaster Management as a Multi-Phased Perspective}

Disaster management has been widely recognized as the crucial strategy of natural and man-made disaster recovery and resilience building in many countries [37]. In the tourism context, the disastermanagement process is an important strategy to enhance the preparedness of destinations and facilitate tourism revitalization from catastrophes $[25,44]$. The process involves multiple phases and a cycle of tackling crises [26,45], which follow a proactive approach in turning responses to readiness for the future [46]. Due to the physio-geographical, socio-cultural, economic, political, and other reasons, some countries are more capable of managing disaster occurrence and recovery than others $[8,47]$.

Whereas the global risk of disasters is intensifying and more uncertain, especially regarding natural disasters, many destinations have considered tourism as having a dual and reciprocal role of powerhouse to local community regeneration, but also a vulnerable resource base that complicates the emergency planning and management to protect lives, property, and environments [10,48-51]. Increasing and intensifying tourism development also exposes tourists and local people to greater risks of disasters [52]. Nevertheless, successful disaster management has a clear connection with sustainable tourism development $[26,53]$ since different types and characteristics of disasters have been found to exert different influences on tourist flow and motivations [8]. 
Although some natural disasters are highly fluid and unpredicTable $[5,8,54]$, decision makers must still undertake a more proactive approach to learn from experiences in each disaster case [29]. Tourism is regarded as a traveling process from visitor-generating regions, to destinations through transit areas. Across these places, natural disasters not only affect a certain geographical location, but a time-space context, where visitors, residents, and various industries exist simultaneously $[8,55]$. This phenomenon shows that the disasters tend to cause impacts on multiple stakeholders of the place simultaneously, and tourism development is connected to the whole disaster occurrence process (i.e., before, during, and after) [56,57]. It is, therefore, essential to understand thoroughly how tourism stakeholders consider their roles and inter-relationship in each phase of the disaster-management process [19].

\subsection{Tourism Stakeholders in Disaster-Management Process}

Tourism stakeholders can be broadly classified into three types, namely, the public sector (governments and public authorities), the private sector (tourism industries, private enterprises, and businesses), and the third sector (other actors such as non-governmental organizations and communities) [58]. Although, having conditional disparities, destinations facing natural disasters may have some common circumstances attributed to stronger abilities for environmental resilience and disaster recovery [59]. Many destinations, however, have been suffering from the lack of communication between stakeholders and disaster-management strategies [46]. One of the key determinants of the success of the disaster-management process is the presence of stakeholders who thoroughly understand the destination needs and collaborate effectively before, during, and after the occurrence of a disaster [48,51]. Often, stakeholders should function well to cooperate under emergency management, share information efficiently across the sectors, and create local knowledge that enhances the resilience of destinations $[46,47,60,61]$. However, contingency theory [62] proposed that the complexity and dynamism of environments, such as destination socio-political and management cultures, amongst individual stakeholders tend to complicate the real-world situation, and ultimately turn disasters into larger-scale and impactful crises $[27,45,63,64]$.

The relationships between stakeholders are diverse but effective collaborations are very important in mitigating the hazardous impacts, enacting emergency planning, and restoring local communities $[53,65,66]$. Stakeholders in tourism industries may connect different actors of the affected destination through the integration of individual actions, looking forward to strategies for coping with long-term destination recovery and sustainability [67]. Although tourism industries have often been criticized as sensitive to disasters and having low resilience [68], their stakeholders could bring partnership and collaboration in building mutual trust [69] under shared but limited resources during the post-disaster period [56]. The interrelationship and perception among stakeholders could also influence decisions related to post-disaster recovery that may strengthen the level of preparedness $[11,26,65]$ and promote higher inclusivity in future disaster management $[51,55]$.

Sawalha [68] classified stakeholders and organizations into three types, namely, (1) reactive to impacts of disasters, (2) proactive to focus on risk management and planning, and (3) inclusive to understand both reactive and proactive approaches. On the one hand, Filimonau and de Coteau [49] reviewed a pool of tourism-related management literature $[48,55,70]$ and identified 18 factors contributing to organizational resilience. The result revealed that adaptability, collaboration, innovation, and human resources were the key determining factors for success [49]. On the other hand, stakeholders often face common challenges, such as the complexity of the disaster-management process, ineffective communication, and imbalance of power and resources [71]. It is, therefore, crucial to study the experiences of local tourism stakeholders in considering the contribution of tourism to disaster processes and perceiving the interconnection with each other $[41,46]$ through an empirical case, for example, the Eastern Iburi earthquake occurrence in Hokkaido Prefecture, Japan in September 2018. 


\section{Research Methodology}

\subsection{Research Gap and Objectives}

In this study, there are two areas of knowledge deficiency with more research requirements. Firstly, relatively less attention has been paid to post-disaster sustainable destination development, such as recovery and resilience building for local communities and tourism stakeholders [70,72,73]. Secondly, the perception of tourism industries and stakeholders were often empirically examined either as a single type of industry actor (e.g., [74]), or as a combination of relational networks $[6,63]$. However, scholars have pointed out that many previous studies have taken a reactive stance on disaster responses and recovery, rather than a holistic process from the planning, preparedness, and management perspective [46,75]. Some scholars further stressed the lack of studies that integrate disaster management in the context of destination management $[46,49]$.

Under the theoretical background discussed above, this paper aims to bridge this research gap by examining a disaster-destination-stakeholders triangulation considered by tourist destination actors $[37,49,68,76,77]$ through an empirical case of an earthquake that happened in southeast Hokkaido, Iburi earthquake in Japan in September 2018 ("the 2018 Hokkaido earthquake"). The investigation is based on the six-phase frameworks of tourism disaster management proposed by Faulkner [25] and Ritchie [26]. Through the face-to-face interviews with a series of invited tourism actors in southern Hokkaido, especially Sapporo city and its surrounding destinations [30], the research objectives were twofold: (1) to elucidate how local tourism actors view their functions as stakeholders who contributed to the destination in each phase of the 2018 Hokkaido earthquake and (2) to identify their key perceived determinant to the success of the disaster-management process and tourism resilience throughout the earthquake occurrence based on the reviewed factors by Filimonau and de Coteau [49].

There is a clear dearth of knowledge about how local tourism stakeholders perceive, communicate amongst, and collaborate with each other in a disaster-destination time-space context [11,46,70,72,78,79], and particularly under the cultural influence of a multi-stakeholder perspective [48]. The interviews were considered reliable and valid sources of information since the respondents are local tourism specialists and industry actors in the destination whose points of view provided solid descriptions to represent the overall state of stakeholders, and provide academic significance and practical recommendations to further enrich the knowledge about stakeholder relationships and cultures in the disaster process in Hokkaido area.

\subsection{Study Area}

The Hokkaido Eastern Iburi earthquake, measuring a magnitude of scale M 6.7, occurred on 6 September 2018 [77] (Figure 1). The disaster caused 41 fatalities and serious damage to the local infrastructure [78]. Electricity suspension was the main issue consequence as nearly 3 million households lost power supply [80-83].

\subsection{Methodology}

This research is exploratory in nature, which applied qualitative research design and a case study approach to advance a theoretical basis of natural disaster management and destination recovery $[84,85]$. The research team conducted face-to-face interviews with the key informants and local tourism stakeholders in Hokkaido in Japan, which was considered an appropriate approach to respond to the research objectives. The interview questions aimed at elucidating local tourism stakeholders' experience in the 2018 Hokkaido earthquake, particularly their view on their contributions and interconnections to the disaster-management process in the earthquake. The list of structured questions was based on the six phases of the disaster-management process by Faulkner [25] and Ritchie [26], as shown in Table 1, which were further adopted in previous studies (e.g., by $[19,27-29,37,77])$. After the structured questions, the researchers extended further discussion with the interviewees for more elaborations on the experience of the earthquake. 


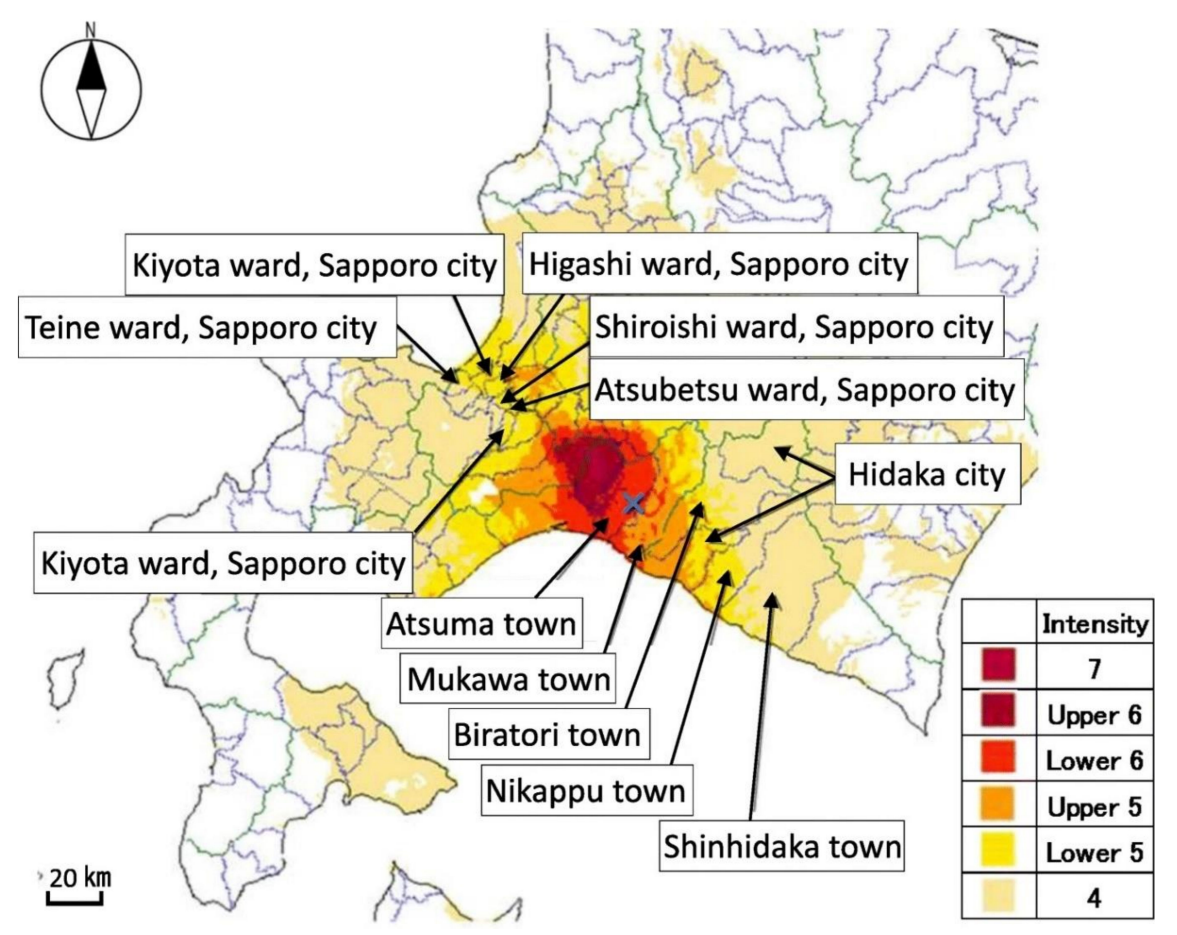

Figure 1. The location of 2018 Hokkaido earthquake. (Source: reference [82]).

Table 1. Interview questions about the contributions of tourism stakeholders to the 2018 Hokkaido earthquake.

\begin{tabular}{|c|c|c|}
\hline $\begin{array}{l}\text { Phase in Disaster } \\
\text { Process [25] }\end{array}$ & $\begin{array}{c}\text { Anatomy of a } \\
\text { Crisis/Disaster [26] }\end{array}$ & Questions \\
\hline Pre-event & $\begin{array}{l}\text { Action taken to prevent } \\
\text { disasters }\end{array}$ & $\begin{array}{l}\text { 1. How may tourism contribute to prepare for a natural } \\
\text { disaster in your destination? Which party is the } \\
\text { most important? }\end{array}$ \\
\hline Prodromal & $\begin{array}{l}\text { Apparent a crisis/disaster } \\
\text { is about to hit }\end{array}$ & $\begin{array}{l}\text { 2. What might the tourism industry do to prepare for } \\
\text { an upcoming natural disaster in your destination? } \\
\text { Which party is the most important? }\end{array}$ \\
\hline Emergency & $\begin{array}{l}\text { Incident hits; damage } \\
\text { limitation and action } \\
\text { needed }\end{array}$ & $\begin{array}{l}\text { 3. What could the tourism industry do to minimize the } \\
\text { immediate damage and impact caused by the natural } \\
\text { disaster in Hokkaido? Which party is the } \\
\text { most important? }\end{array}$ \\
\hline Intermediate & $\begin{array}{l}\text { Short-term needs dealt } \\
\text { with; restoring services }\end{array}$ & $\begin{array}{l}\text { 4. How might tourism contribute to the short-term } \\
\text { restoration of your destination after a natural } \\
\text { disaster? Which party is the most important? }\end{array}$ \\
\hline $\begin{array}{l}\text { Long-term } \\
\text { (recovery) }\end{array}$ & $\begin{array}{l}\text { Longer term clean up; } \\
\text { repair, reinvestment; } \\
\text { post-mortem }\end{array}$ & $\begin{array}{l}\text { 5. How might tourism contribute to the long-term } \\
\text { recovery of your destination from a natural disaster? } \\
\text { Which party is the most important? }\end{array}$ \\
\hline Resolution & $\begin{array}{l}\text { Normal or improved } \\
\text { state created }\end{array}$ & $\begin{array}{l}\text { 6. Could tourism contribute to a new and improved } \\
\text { state of development after a natural disaster in your } \\
\text { destination? Which party is the most important? }\end{array}$ \\
\hline
\end{tabular}

\subsection{Data Collection Process}

The interviews, which represented a suiTable method that allows guided freedom of responses [86], were conducted in August 2019, approximately one year after the earthquake occurrence. The interviewed tourism actors and key informants in three major areas of expertise or work included academic research, public authorities, and the private sector, as well as those that experienced the 2018 Hokkaido earthquake, 
which mainly included people located in Sapporo (the capital city of Hokkaido Prefecture) and its surrounding major tourist destinations, such as Niseko Village, Toyako, and Noboribetsu areas. The interviewees were invited through the research team invitation since it was difficult to plead with all the tourism industry representatives and organizations to participate. These interviewees were considered representatives of the tourism industries because of their ongoing engagement in tourism development, operations, and research in Hokkaido.

The face-to-face interviews were voluntary and were arranged through prior appointments and walk-in requests by the researchers during the field investigation. There were 15 participants for 9 separate in-depth interviews since some interviews included more than one representative from an organization and, thus, had a group interview. Consent was obtained from the interviewees and the participant list is shown in Table 2; however, codes would be used for identifying responses in the subsequent analysis. The interviews persisted between $1 \mathrm{~h}$ to $1.5 \mathrm{~h}$ in Japanese or English.

Table 2. Profiles of the interviewees.

\begin{tabular}{ll}
\hline Duration & Interviewee (code) \\
\hline $1 \mathrm{~h}$ & $\begin{array}{l}\text { (A1) Prof. Chiaki SHIMOYASUBA, Professor, Center for Advanced Tourism Studies (CATS), } \\
\text { Hokkaido University }\end{array}$ \\
\hline $1 \mathrm{~h}$ & (A2) Prof. Yutaka ASAZUMA, Professor, Faculty of Economics, Hokkai-Gakuen University \\
\hline $1 \mathrm{~h}$ & $\begin{array}{l}\text { (A3a) Mr. Hitoshi HATTORI, Operations Manager, Hilton Niseko Village } \\
\text { (A3b) Mr. Kohei IWATA, Chief Concierge of Hilton Niseko Village }\end{array}$ \\
\hline $1.5 \mathrm{~h}$ & (A04) Mr. Ross FINDLAY, Managing Director, Niseko Adventure Centre (NAC), NAC Co. Ltd. \\
\hline $1.5 \mathrm{~h}$ & $\begin{array}{l}\text { (A05a) Mr. Takashi TANI, Associate Manager, Department of Tourism Promotion, Toyako Town Government } \\
\text { (A05b) Mr. Kazuo YANO, Officer, Department of Tourism Promotion, Toyako Town Government }\end{array}$ \\
\hline $1.5 \mathrm{~h}$ & $\begin{array}{l}\text { (A06a) Mr. Takanobu SHIMIZU, Deputy Secretary General, Noboribetsu International Tourism and } \\
\text { Convention Association } \\
\text { (A06b) Mr. Masato HIEI, Senior Staff, Noboribetsu International Tourism and Convention Association }\end{array}$ \\
\hline \multirow{2}{*}{$\mathrm{h}$} & $\begin{array}{l}\text { (A07a) Mr. Hayato HITO, General Manager of Promotion, Hokkaido Tourism Organization (HTO) } \\
\text { (A07b) Mr. Hiroshi KINOSHITA, General Manager of Planning, Hokkaido Tourism Organization (HTO) } \\
\text { (A07c) Ms. Shizue ISHIBASHI, Officer, Hokkaido Tourism Organization (HTO) } \\
\text { (A07d) Ms. Saori IKEMOTO, Officer, Tourism Promotion Division, Department of Economic Affairs, } \\
\text { Hokkaido Prefecture Government }\end{array}$ \\
\hline $1 \mathrm{~h}$ & $\begin{array}{l}\text { (A08) Prof. Yusuke ISHIGURO, Associate Professor, Center for Advanced Tourism Studies (CATS), } \\
\text { Hokkaido University }\end{array}$ \\
\hline
\end{tabular}

The research team tape-recorded, translated, and fully transcribed the interviews verbatim with the participants' permission. This process was considered appropriate as all the dialogues and interactions during the interviews could be accurately transformed into the information for analysis [87]. One researcher and two independent research assistants separately interpreted and coded the transcripts. The process of information codification was based on a hybrid deductive and inductive approach that combined the research objectives and framework, and the empirical evidence from the interviews [88]. The transcripts went through thematic analysis in an attempt to examine the major ideas of the views of the interviewees on the contributions of tourism to the disaster phases [89].

\subsection{Methods of Data Analysis}

Thematic content analysis is a research technique for making replicable and valid inferences based on a systematic process of comparing, contrasting, and categorizing the responses obtained from the interview communications $[89,90]$. This method was complemented by the holistic-content perspective of narrative analysis, which searched for repeated topics in a narrative such as a set of interview transcripts to capture an overall impression of the theme [91]. Combining theory-based and data-driven approaches [90,92], the codification followed the six-phase disaster-management frameworks of Faulkner [25] and Ritchie [26]. However, the researchers manifested the themes by 
referring to the interview content of the analysis. The screening process particularly focused on how the interviewees (stakeholders) expressed their views on the factors contributing to organizational resilience for Hokkaido recovery from the earthquake [49] and the roles, positions, and attitudes toward disaster management [68].

\section{Results}

\subsection{Tourism Stakeholders in the Disaster-Management Process}

The pre-disaster phase often refers to the period of impact prevention and mitigation planning, which is deemed more superior to post-disaster recovery [33,93], when the risk of natural disasters is unavoidable in those hazard-prone destinations. According to the interviewees, disaster preparedness in Hokkaido refers to the actions of experience sharing (A01, A06a), securing electricity supply and communication channels (A02, A07a, A09), fire drills and evacuation demonstrations (A03a, A05a, A09), risk management (A04), and accurate and timely information provision to tourists (A06a, A07d). Some interviewees tended to focus on institutional dimensions of, for example, launching a certification system to increase the disaster prevention awareness and education (A05), consolidating organizational effort across different actors (A02), as well as establishing a management council and management system for the preparatory work of disasters (A06a, A08). It has been criticized that the absence of centralized information coordination for the tourism disaster management process is undesirable in the case of Hokkaido (A07a). All these actions require more financial support from the national government (A08).

For the prodromal phase for largely unpredicTable earthquakes [5], many interviewees considered that destinations like Hokkaido could provide material support such as power-generation equipment (A01, A05a, A06a, A06b, A07d), food (A02), evacuation arrangements (A07a), network communication (A07d), and temporary accommodation (A07d, A09).

Similar to the circumstances in other destinations [10,11,48-51], tourism industries and activities in Hokkaido were suspended and not focused on during the emergency phase immediately after the natural disasters. All the actions, resources, and attention were diverted towards locating and handling immediate evacuation, rescue, and damage confirmation after a sudden natural catastrophe such as earthquakes. This idea persists in the case of the 2018 Hokkaido earthquake (A01, A02, A04, A08). Tourism businesses in loco such as accommodation providers had to onshore a limited level of services to the guests (A03b, A06a). The condition of emergency is largely determined by the resistance of construction and infrastructure (A06a), the availability of immediate information (A07a, A07b), and effective communications (A09), as reflected in the Hokkaido case [4].

A destination enters into an intermediate phase when the emergency of natural disaster has become stabilized and all the relevant actors in the destination would have the capacity and ability to initiate some quick solutions and reactions to tackle short-term recovery circumstances. In Hokkaido, many interviewees mentioned post-disaster destination promotion (A05a, A05b, A09), experience sharing on emergency management (A07a), and "Fukkou-wari", that is, the restoration discount scheme launched by the national government (A01, A02, A07b), which was similar to the Kumamoto earthquake restoration in 2016 [19], although such financial incentive was not fully supported (A08). Whereas resuming the region's "normal" was a primary goal (A04), more stakeholders proposed relatively long-term actions such as tackling negative image (A05a, A05b, A09), developing domestic tourism, promoting local attractions for local people, establishing good communications, creating connections among tourism stakeholders in the whole city (A06a, A06b), and realizing the quality of tourism (A08) and loyalty development (A09).

The abovementioned responses tended to overlap with those in the long-term recovery phase, when tourism regains a more substantial role in revitalizing the local economy but requires more strategic planning for policy and economic regeneration. Intensifying destination promotion (A01, A04, A05a, $\mathrm{A} 07 \mathrm{a})$, enhancing positive image (A01, A03b), and providing accurate information to the public (A01, A02, 
A08, A09) were the key recovery actions. However, a stronger connection between tourism development, industries, and local communities should be realized in the disaster period [28,39], for example, through the provision of free services to local people (A06a, A06b) and public-private partnerships (A08).

Lastly, the resolution phase in the case of the Hokkaido earthquake goes beyond the strategy of disaster recovery only, although it is observed that some interviewees did regard the post-disaster environment as the "resumed" or pre-disaster condition. However, there were voices suggesting the perspective of sustainable development of the affected destination. According to the interviewees, destination and place sustainability refers to the connections between different groups of people, stakeholders, and local communities (A01, A03b, A08, A09); the development of local knowledge and creativity (A01, A02, A06a); and the enhancement of the visitor experience and safety perception (A03b, A07b). The core idea of such an improved state aims to innovate the whole disaster-management system (A06a, A07a) and transform the destination into a better place for everyone [91].

\subsection{Actors and Actions for the Disaster-Management Process and Destination Resilience}

The analysis counted the number of quotes of self-reported key stakeholders leading to each resilience component for a destination in the disaster process. According to such frequencies, communication, survival, and management strategies were the top three components contributing to the largest share of quotes $(29.74 \%, 20.86 \%$, and $17.28 \%$, respectively). On the contrary, flexibility, organization's structure, situation awareness, and human resources were the bottom four components that were mentioned only once throughout the interviews with a share of $0.22 \%$ for each quote.

Local tourism stakeholders expressed a relatively even distribution of destination resilience components, ranging from $13.30 \%$ to $20.40 \%$ across the six disaster phases. However, three types of components were identified, which are more focused on the earlier phases (e.g., survival, learning, agility, management of vulnerabilities), diverted to the later phases (e.g., financial resources, disaster-management strategies, strong leadership, innovation, management strategies), and appeared across the whole process (e.g., communication, collaboration, planning). Instead of a lengthy presentation of numbers and counts, Figure 2 graphically illustrates the resilience components connected to tourism stakeholders in the disaster process of the 2018 Hokkaido earthquake.

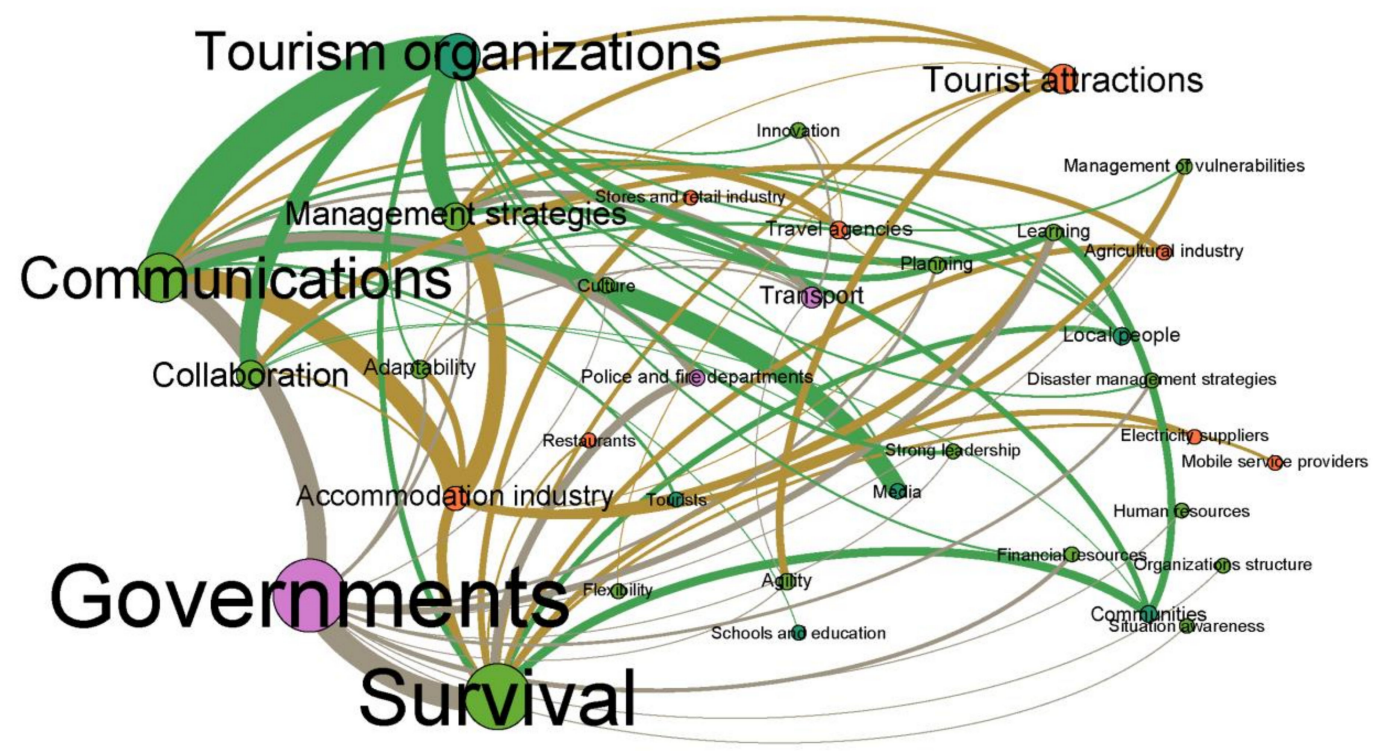

Figure 2. The resilience components connected to tourism stakeholders in the disaster process of the 2018 Hokkaido earthquake.

Based on the classification of organizational resilience components by Filimonau and de Coteau [49], Table 3 further deduces these components through the analysis of the actions taken or considered 
by the stakeholders in the interviews. The content investigation detects that communication (12), adaptability (8), survival (6), management strategies (6), and learning (6) have comparatively more actions (sub-codes) taken or considered by the interviewees.

Table 3. Actions for destination resilience reported by interviewees.

\begin{tabular}{|c|c|}
\hline $\begin{array}{c}\text { Resilience } \\
\text { Component/Code }\end{array}$ & Actions/Sub-Codes (Frequency) \\
\hline Communication & $\begin{array}{l}\text { Share accurate information; notify across the stakeholders about the situation; offer prompt } \\
\text { assistance to foreigners; give suggestions to locals; follow governmental advice; translate } \\
\text { information to foreigners; collect and disseminate information about damage; establish } \\
\text { information-sharing platforms and communication channels; post and update information } \\
\text { online; report and disseminate updated statistics; improve information management (11) }\end{array}$ \\
\hline Survival & $\begin{array}{l}\text { Accommodate evacuees; secure power supply; provide food and water stock, petrol, daily } \\
\text { necessities, and emergency kits; assure tourists' safety and evacuation; save people in the } \\
\text { neighborhood; keep people warm in winter (6) }\end{array}$ \\
\hline $\begin{array}{l}\text { Management } \\
\text { strategies }\end{array}$ & $\begin{array}{l}\text { Reflect administrative process; launch discount coupon schemes; improve service quality; } \\
\text { balance the needs of residents and tourism activities; integrate agriculture and tourism; } \\
\text { initiate regional development and management (6) }\end{array}$ \\
\hline Collaboration & $\begin{array}{l}\text { Connect between industries; connect between regions; build up networks and } \\
\text { relationships; coordinate with stakeholders (4) }\end{array}$ \\
\hline Learning & $\begin{array}{l}\text { Learn from experience; create disaster prevention and emergency manual; initiate disaster } \\
\text { prevention education; conduct academic research and disaster analyses; organize } \\
\text { workshops for tourism enterprises and industries; make reference to other hazard-prone } \\
\text { destinations (6) }\end{array}$ \\
\hline Adaptability & $\begin{array}{l}\text { Organize disaster-preparation drills; change business model and practices; develop and } \\
\text { strengthen infrastructure construction; increase earthquake resistance; change to safer } \\
\text { activities; establish transportation hubs for disaster and emergency use; explore new areas } \\
\text { of residence; change lifestyle (8) }\end{array}$ \\
\hline Planning & Formulate policies; develop rescue, recovery, master and sustainability planning (2) \\
\hline Agility & $\begin{array}{l}\text { Resume transport system efficiently and effectively; check disaster conditions on the } \\
\text { Internet; show the recovery progress timely to the public (3) }\end{array}$ \\
\hline $\begin{array}{l}\text { Management of } \\
\text { vulnerabilities }\end{array}$ & $\begin{array}{l}\text { Increase earthquake resistance; minimize economic impact; provide mental comfort and } \\
\text { healing for citizens; eradicate tourists' fear (4) }\end{array}$ \\
\hline Financial resources & Provide financial support; prepare emergency budget and funding (2) \\
\hline $\begin{array}{l}\text { Disaster-management } \\
\text { strategies }\end{array}$ & $\begin{array}{l}\text { Start risk management; establish emergency-management organizations; create risk and } \\
\text { disaster mapping ( } 2 \text { ) }\end{array}$ \\
\hline Strong leadership & $\begin{array}{l}\text { Cheer up local people and communities; organize reconstruction works systematically; } \\
\text { take the leadership to collaborate stakeholders (3) }\end{array}$ \\
\hline Innovation & $\begin{array}{l}\text { Develop alternative and new tourism resources; develop new business areas, products, } \\
\text { and services, e.g., trains for sightseeing; explore local specialties; show creativity and } \\
\text { convenience to the public (4) }\end{array}$ \\
\hline Culture & $\begin{array}{l}\text { Protect local people, culture, and facilities; develop multilingual apps and information; } \\
\text { support departure of international tourists; show confidence and local spirit (4) }\end{array}$ \\
\hline Flexibility & Prepare places turning into emergency and evacuation use (1) \\
\hline $\begin{array}{l}\text { Organization's } \\
\text { structure }\end{array}$ & Establish preparatory and disaster-management council or unit (1) \\
\hline Situation awareness & $\begin{array}{l}\text { Inspect and confirm onsite damage; update statistics; understand the needs, situations, } \\
\text { and difficulties of residents and tourists (3) }\end{array}$ \\
\hline Human resources & Assist frontline staff; encourage volunteers and external support (2) \\
\hline
\end{tabular}

\subsection{Stakeholders' Position on Destination Resilience}

According to the classification of stakeholders into their positions based on resilience by reference [9], the research interpreted the interviewees' attitudes toward resilience across the six phases 
of the 2018 Hokkaido earthquake. Based on the examination of the interview scripts, the outcome in Table 4 shows that interviewees tend to consider how Hokkaido tourism stakeholders have behaved and actualized the disaster management.

Table 4. Classification of stakeholders into position on resilience.

\begin{tabular}{lcccccc}
\hline & Phase 1 & Phase 2 & Phase 3 & Phase 4 & Phase 5 & Phase 6 \\
\hline $\begin{array}{l}\text { Reactive to impacts of disasters } \\
\begin{array}{l}\text { Proactive to focus on risk } \\
\text { management and planning }\end{array}\end{array} \quad 4$ & 2 & 6 & 2 & 6 & 5 \\
$\begin{array}{l}\text { Inclusive to understand both } \\
\text { reactive and proactive approaches }\end{array}$ & 2 & 1 & 2 & 9 & 3 & 4 \\
Not identified & 6 & 7 & 7 & 4 & 5 & 5 \\
\hline
\end{tabular}

(Remarks: Adopted from reference [68]).

The results elucidate that not all the interviewees demonstrated a clear pattern of stakeholders' behavior for destination resilience in Hokkaido. The biggest difference is situated between phases 3 (emergency) and 4 (intermediate). More interviewees tended to believe that tourism stakeholders have been reactive in the emergency phase of the earthquake but engaged in a proactive approach to tackle risk management and planning in the intermediate phase shortly after the disaster.

Figure 3 illustrates graphically the degrees of contribution by tourism stakeholders to each disaster-management stage. The magnitude of contribution was evaluated based on the referenced actions (percentages of sub-codes) identified in the content of the interviews. The result reveals that all three sectors (public, private, and third) appear to take more actions in the pre-event phase (stage 1) than other phases in the disaster-management process of the 2018 Hokkaido earthquake.

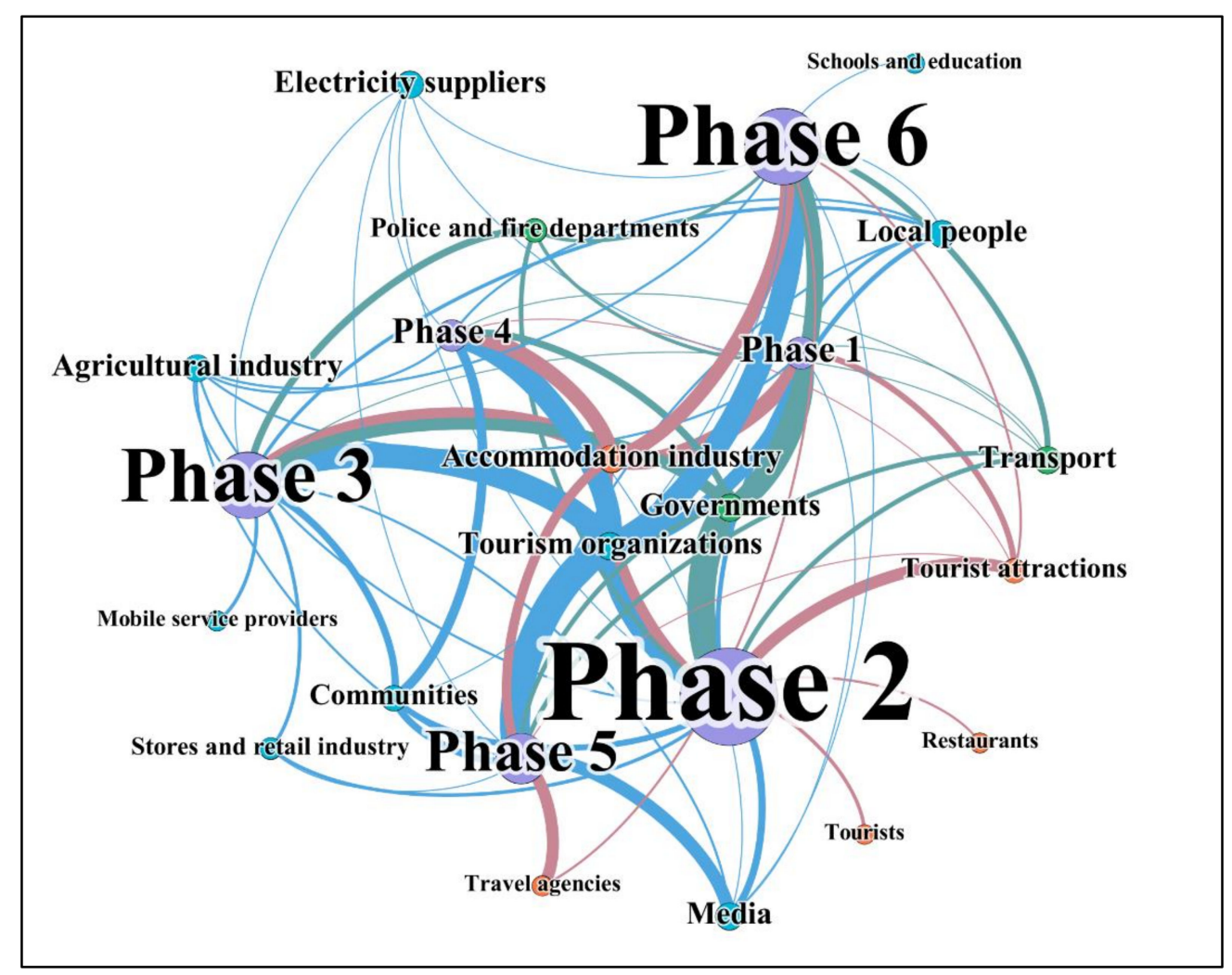

Figure 3. The interconnection of stakeholders in each disaster-management stage in the 2018 Hokkaido earthquake. 


\section{Discussion}

\subsection{Stakeholders' Views on Tourism Contributions to Disaster Management across Disaster Phases}

The pre-event stage observes multi-functionality in terms of two aspects. Firstly, tourism resources and spaces are flexible for disaster preparation, for example, through changing the uses of accommodation and tourist facilities [11]. Secondly, stakeholder groups, people, and tourism industries could also play multiple roles during different circumstances including the normal times and any predicted occurrence of natural disasters, e.g., weather-related hazards. Sharing the responsibility between stakeholders such as public authorities and local people is the key for preparedness as reflected in previous studies [63].

In the prodromal phase of certain predicTable disasters, (1) evacuation and emergency arrangements and (2) the preparation of physical materials and necessities for an emergency, such as power supply, are the two major areas of actions contributed by tourism to the destination. In the emergency phase, tourism is considered less important since the affected areas should focus on the immediate evacuation and rescue arrangements $[19,33]$. However, connecting to the pre-event stage, tourist resources and spaces are often converted into immediate support and emergency accommodation to the disaster refugees. Tourism actors in the industries also contribute to confirm the safety conditions and information about the damage in tourism-related sites. Responses to these two phases share some similar findings that highlight communication effectiveness [43] and information accuracy as shared by other researchers $[4,51,94,95]$.

The intermediate phase is largely economy-oriented restoration of tourism functions and business operations, through actions including destination promotion and image improvement. Nevertheless, some stakeholders also emphasize the possibility of creating new products and services to attract the return of tourists and development of domestic markets. Although these actions mainly tackle short-term restoration of the affected destination, they have connected to a greater variety of opportunities and visions.

Destination promotion and image improvement and creation of new products and services to attract the return of tourists are both extended from the short-term actions to part of the long-term recovery consideration [75] through the provision of accurate destination information to the media and the public [35]. The effect of both mass [96] and social media is critical [50] in Japan due to the stronger language and communication barriers between local and inbound visitors, and its natural hazard-prone background [4,63]. An effective communication system across stakeholders would benefit the entire disaster-management process $[97,98]$. More discussions are placed on the exploration of new forms of tourism as post-disaster development opportunities, the institutional reform or improvement for community revitalization, and the establishment of supporting systems across the geographical areas and sectors.

Lastly, in the resolution phase, the stakeholders take into consideration a sustainable development perspective from changing the local lifestyle, strategies of sustainable tourism development, improvement in living environments, accumulation of local knowledge and creativity, and, one important step going forward, establishment of strong people-to-people and people-to-place connections. The former could be attained through increasing tourism stakeholder collaborations with information and experience sharing. The latter could be in the form of enhancing the post-disaster visitor experience by engaging local communities.

\subsection{Stakeholders' Views on Tourism Contributions to Disaster Management across Disaster Phases}

Table 5 compares the observations in the 2016 Kumamoto earthquake [19] and the 2018 Hokkaido earthquake, regarding the disaster-management responses and the actions proposed and taken by tourism stakeholders. Several aspects of similarities and differences between the two destinations are observed. 
Table 5. Comparison of disaster-management responses between Kumamoto and Hokkaido observations.

\begin{tabular}{|c|c|}
\hline $\begin{array}{l}\text { Phases of Disaster Process [25]; } \\
\text { Anatomy of a Crisis/Disaster [26] }\end{array}$ & Role of Tourism from Hokkaido Observations (the Current Study) \\
\hline Pre-event (stage) & $\begin{array}{l}\text { - Multi-functional tourism resources and spaces for } \\
\text { disaster preparation } \\
\text { - Multi-functional groups of stakeholders, people, and tourism } \\
\text { industries for disaster preparation }\end{array}$ \\
\hline Prodromal & $\begin{array}{l}\text { - Evacuation and emergency arrangements } \\
\text { - Preparation of physical materials and necessities for emergency, } \\
\text { such as power supply }\end{array}$ \\
\hline Emergency & $\begin{array}{l}\text { - Immediate evacuation arrangements } \\
\text { - } \quad \text { Confirmation of safety conditions and information in } \\
\text { tourism-related sites } \\
\text { - Provision of immediate support and emergency accommodation to } \\
\text { disaster refugees }\end{array}$ \\
\hline Intermediate & $\begin{array}{l}\text { - Short-term restoration of tourism functions and business operation } \\
\text { - Creation of new products and services to attract the return of tourists } \\
\text { and development of domestic markets } \\
\text { - Destination promotion and image improvement }\end{array}$ \\
\hline Long-term (recovery) & $\begin{array}{l}\text { - Provision of accurate destination information to the (mass and social) } \\
\text { media and the public } \\
\text { - } \quad \text { Creation of new products and services to attract the return of tourists } \\
\text { Exploration of new forms of tourism as opportunities from } \\
\text { the disaster } \\
\text { - Institutional reform or improvement for community revitalization } \\
\text { Establishment of supporting system across geographical areas } \\
\text { and sectors }\end{array}$ \\
\hline Resolution & $\begin{array}{l}\text { - Consideration of sustainable development perspective from local } \\
\text { lifestyle, sustainable forms of tourism, living environments, local } \\
\text { knowledge, and creativity } \\
\text { - Tourism stakeholder collaborations with information and } \\
\text { experience sharing } \\
\text { - } \quad \text { Enhancement of post-disaster visitor experience } \\
\text { - Strong connections between local and non-local people, and the place }\end{array}$ \\
\hline
\end{tabular}

Firstly, across the six phases of disaster, relatively more aspects appear in the post-disaster situations. Both Kumamoto and Hokkaido cases clearly show a focus on physical resources during the preparatory stages; then image regeneration and promotion for disaster recovery; and a visionary, relational, and institutional reform for long-term resolution and destination sustainability. Due to the environmental and situational disparities, the attributes of disaster actions in the two places tend to be different. The responses in both studies similarly confirm that post-disaster phases often offer a learning opportunity for destinations and their tourism industries to "redefine" the outcome or resumed state through (re)development $[18,99]$.

Secondly, Ryokan resorts (traditional small-scale Japanese-style lodges) are popular in the Kumamoto region (e.g., Kurokawa Onsen) while larger hot spring and conventional guesthouses are more common in the Hokkaido region. The functions and operation of these two types of accommodation serve differently in the disaster process. Hotels or touristic guesthouses contribute to disaster preparedness since these facilities could turn into evacuation sites and become a short-term refuge for both tourists and local populations. The Ryokan shows a traditional kind of local operation culture where safety and quality of services for its in-residence guests are of paramount importance even after disaster occurrence $[100,101]$.

Thirdly, knowledge management appears to be a highlighted area of concern in both Kumamoto and Hokkaido cases. However, tourism stakeholders in Kumamoto believed that knowledge about 
natural hazards was critical for increasing awareness by the public, tourists, and industry actors in disaster preparedness $[19,58,77,102,103]$. In Japan, both local communities and public authorities have collected materials related to the historical information about the community-based experience and adaptation to disasters (e.g., earthquake records) over decades across generations, especially after several massive disasters, after the millennium. These efforts ultimately achieved cultural identity, community sustainability, disaster preparedness, mitigation, reconstruction, and resilience. These collective efforts have involved multiple stakeholders including volunteers, archiving organizations, and local governments [104], although coordination of stakeholder groups is important to prevent unnecessary catastrophic situations [105]. In Hokkaido, emphasis is placed on how local knowledge from the communities could be accumulated and consolidated in the whole disaster process [56] (Figure 2).

Moreover, destination governance and management culture could also bring about disparities in tourism stakeholder and industry reactions through network theories, stakeholder communications [51], and transformation of personal value into organizational culture [63]. Kumamoto region has developed a stronger "local spirit" with the creation of mascot ("Kumamon"), which strengthens and reinforces host-guest connections in recovery [19]. Such tourism-to-people integration in Hokkaido was found to be weaker in this empirical investigation even though the area is more popular in terms of tourist arrival and destination development.

Although the magnitude and impacts of the two earthquakes were different, such dynamic and disastrous circumstances would lead to more proactive responses from tourism industries to handle similar future situations [106], which could positively strengthen the overall preparedness [65], innovativeness [107], and resilience of the destinations [108].

\subsection{Factors Affecting Destination Resilience in Hokkaido}

This study reveals that communication, survival, management strategies, collaboration, and learning are the most significant resilience components of Hokkaido as a tourist destination. This result only matches the findings of Filimonau and de Coteau's [49] review with just one common determinant: collaboration (Table 3). Nevertheless, the most important factors identified in this study confirmed the role of people (survival), processes (management strategies and learning) [98], and networks (communication and collaboration) suggested by Hall [78], Hall et al. [70], and Ma et al. [4].

Learning from the interviews, tourism industries and stakeholders in Hokkaido lacked any integrated disaster-management plans and stakeholder collaboration, which have been a common problem in many parts of the world as criticized by researchers $[37,45,49,53,66]$. Scholars have stressed that tourism stakeholders should more actively embrace disaster-management practices and closely integrate them into the destination-management agenda $[109,110]$. Table 5 reveals that local tourism stakeholders tend to perform proactively in risk management in the intermediate phase only. Naturally, during the emergency stage of an earthquake, tourism industries were reactive to disaster impacts since this issue is highly determined by the nature and the situational conditions of the affected destination.

The aforementioned destination management culture is similar to how the business sector adapts to disasters from growing awareness to the development of long-term strategic thinking and corporate measures in mitigating and minimizing negative impacts [55]. Two possibilities exist, firstly, to identify and protect vulnerable local culture, and, secondly, to employ cultural characteristics of certain communities to improve the overall preparedness and disaster response [63]. The role of the local third sector in the tourism field should have played a more active role in the disaster-management process since these local non-governmental and non-commercial organizations and stakeholders might have important preparatory functions in pre-disaster phases as shown in Figure 2. As emphasized by reference [58], for example, specific local knowledge possessed by local communities could be "an added value to the tourist experience" although this third sector usually has "no formally recognized role in tourism planning and development" in many destinations [58] (p. 86). 


\section{Conclusions}

The 2018 Hokkaido earthquake had caused some degrees of infrastructure damage (mostly electricity suspension and communication network breakdown) and tourism disruption. The local tourism actors in the affected destination indicated a range of actions across the pre-to-post earthquake period performed or expected. Firstly, the multi-functionality of tourism resources, spaces, and industries are prominent for disaster preparation. Secondly, physical materials and necessities and evacuation and emergency arrangements are the key contributions of tourism during the prodromal and emergency phases, in which information and communication barriers are the major difficulties to be tackled [4,46]. Moreover, the remaining three post-disaster (intermediate, recovery, and resolution) phases demonstrate more possibilities of restoring the affected destination to a state of long-term (re)development, such as product creation, image improvement, local knowledge enrichment, and, more importantly, people-to-people and people-to-place connections. Instead, returning to a "pre-disaster" state is criticized as unrealistic but transforming the destination with more long-term sustainability consideration and vision is supported $[58,93,110]$.

From the destination resilience perspective, the stakeholders that participated in this study share collaboration as the key determinant of an improved Hokkaido region. This factor could integrate stakeholders through shared local values, experiences, and memories in disaster risk communication and strategies for preparedness $[63,111]$. Although the public sector has often had more abundant resources [112], local people and communities are also responsible for the disaster-management and recovery process because they are one of the key beneficiaries and stakeholders [61].

This research advances the theoretical foundation and development of natural disaster management through the exploration of how tourism stakeholders consider the role of tourism across the disaster occurrence process $[19,25,26]$. The study further explores how these stakeholders' views contribute to destination resilience from the perspective of organizational management $[49,110,113]$. These human-related aspects including disaster risk management, destination recovery, and tourism sustainability may be wisely achieved. Natural hazards, however, may be exaggerated to become man-made disasters, which are believed to be voluntary, controllable, attribuTable, and avoidable through risk, crisis, and stakeholder management $[1,10,32]$.

Tourism forms a platform that must involve stakeholders' organization in the disaster-affected destination. People-to-people and people-to-destination integration must be considered in the disastermanagement process, especially during long-term recovery and resolution periods. In territories with diversified cultures of local communities, indigenous groups, and governance, such as Japan and Southeast Asia, more theoretical construction and empirical studies should be undertaken to further understand how stakeholders' networks and power structures work in natural and man-made disasters $[6,67,94]$. This study academically lays down a foundation for a cross-territorial and cross-cultural comparison across two destinations in Japan.

This research is limited by the representation of the informants and fieldwork conducted, since the scope of the interviewees may not cover all types of the stakeholders comprehensively. Surveys on local residents and tourists may be an opportunity to explore this topic area although language barriers and the scale of data collection may impose an obstacle to the study. The qualitative approach carries a degree of subjectivity in the responses and interpretations, although the research team had attempted to minimize such shortcomings in the analytical process.

Author Contributions: Conceptualization, Methodology, Validation, Formal Analysis, Investigation, Resources, Data Curation, Writing-Original Draft Preparation, Writing-Review \& Editing, Supervision, Project Administration, Funding Acquisition, C.-S.C.; Data Curation, Software, Visualization, Q.Z.; Investigation, K.N. All authors have read and agreed to the published version of the manuscript.

Funding: This research was funded by the Sumitomo Foundation, Fiscal 2018 Grant for Japan-related Research Projects (Project code: 188014).

Acknowledgments: The authors would like to thank all the interview participants in this study during the field study in Hokkaido in August 2019. 
Conflicts of Interest: The authors declare no conflict of interest.

\section{References}

1. Huan, T.C. Taiwan's 921 earthquake, crisis management and research on no-escape natural disaster. In Crisis Management in Tourism; Laws, E., Prideaux, B., Chon, K., Eds.; CAB International: Wallingford, UK, 2007.

2. United Nations Office for Disaster Risk Reduction (UNISDR). Living with Risk: A Global Review of Disaster Reduction Initiative; ISDR Secretariat: Geneva, Switzerland, 2002.

3. Huang, J.H.; Min, J.C.H. Earthquake devastation and recovery in tourism: The Taiwan case. Tour. Manag. 2002, 23, 145-154. [CrossRef]

4. Ma, H.; Chiu, Y.; Tian, X.; Zhang, J.; Guo, Q. Safety or travel: Which is more important? The impact of disaster events on tourism. Sustainability 2020, 12, 3038. [CrossRef]

5. Vere-Jones. Forecasting earthquakes and earthquake risk. Int. J. Forecast. 1995, 11, 503-538. [CrossRef]

6. Rittichainuwat, B.N. Tourists' and tourism suppliers' perceptions toward crisis management on tsunami. Tour. Manag. 2013, 34, 112-121. [CrossRef]

7. Akihime, C. Economic impacts on Kumamoto-shi tourism industries. Rep. Tono Res. Inst. Earthq. Sci. 2017, 39, 39-48. (In Japanese)

8. Rosselló, J.; Becken, S.; Santana-Gallego, M. The effects of natural disasters on international tourism: A global analysis. Tour. Manag. 2020, 79, 104080. [CrossRef]

9. Tsai, C.H.; Chen, C.W. An earthquake disaster management mechanism based on risk assessment information for the tourism industries-a case study from the island of Taiwan. Tour. Manag. 2010, 31, 470-481. [CrossRef]

10. Becken, S.; Hughey, K.F.D. Linking tourism into emergency management structures to enhance disaster risk reduction. Tour. Manag. 2013, 36, 77-85. [CrossRef]

11. Nguyen, D.N.; Imamura, F.; Iuchi, K. Public-private collaboration for disaster risk management: A case study of hotels in Matsushima, Japan. Tour. Manag. 2017, 61, 129-140. [CrossRef]

12. Fok, L.; Cheung, L.T.O. Evaluating the impact reduction strategies for the tropical cyclone hazard in Hong Kong. Asian Geogr. 2012, 29, 121-129. [CrossRef]

13. Huan, T.C.; Beaman, J.; Shelby, L. No-escape natural disaster: Mitigating impacts on tourism. Ann. Tour. Res. 2004, 31, 255-273. [CrossRef]

14. Pennington-Gray, L. Developing a destination disaster impact framework. Tour. Anal. 2014, 19, $105-110$. [CrossRef]

15. Yokoyama, H.; Murooka, Y.; Makino, H. Influence on tourism in Kyushu by 2016 Kumamoto earthquake (The second report). In Proceedings of the JITR Annual Conference, Ishikawa Prefecture, Japan, 1-2 December 2017; 32, pp. 337-340. (In Japanese).

16. Gall, M.; Nguyen, K.H.; Cutter, S.L. Integrated research on disaster risk: Is it really integrated? Int. J. Disaster Risk Reduct. 2015, 12, 255-267. [CrossRef]

17. Schmude, J.; Zavareh, S.; Schwaiger, K.M.; Karl, M. Micro-level assessment of regional and local disaster impacts in tourist destinations. Tour. Geogr. 2018, 20, 290-308. [CrossRef]

18. Seraphin, H. Natural disaster and destination management: The case of the Caribbean and hurricane Irma. Curr. Issues Tour. 2019, 22, 21-28. [CrossRef]

19. Chan, C.S.; Nozu, K.; Cheung, L.T.O. Tourism and natural disaster management process: Perception of tourism stakeholders in the case of Kumamoto earthquake in Japan. Curr. Issues Tour. 2019. [CrossRef]

20. UNWTO. COVID-19: Putting People First. 2020. Available online: https://www.unwto.org/tourism-covid-19 (accessed on 9 August 2020).

21. UNWTO. Global Guidelines to Restart Tourism. 2020. Available online: https://webunwto.s3.eu-west1.amazonaws.com/s3fs-public/2020-05/UNWTO-Global-Guidelines-to-Restart-Tourism.pdf (accessed on 9 August 2020).

22. UNWTO. Impact Assessment of the COVID-19 Outbreak on International Tourism. 2020. Available online: https://www.unwto.org/impact-assessment-of-the-covid-19-outbreak-on-international-tourism (accessed on 9 August 2020).

23. Pottorff, S.M.; Neal, D.M. Marketing implications for postdisaster tourism destinations. J. Travel Tour. Mark. 1994, 3, 115-122. [CrossRef] 
24. Young, W.B.; Montgomery, R.J. Crisis management and its impact on destination marketing. J. Conv. Exhib. Manag. 1997, 1, 3-18. [CrossRef]

25. Faulkner, B. Towards a framework for tourism disaster management. Tour. Manag. 2001, 22, 135-147. [CrossRef]

26. Ritchie, B.W. Chaos, crises and disasters: A strategic approach to crisis management in the tourism industries. Tour. Manag. 2004, 25, 669-683. [CrossRef]

27. Miller, G.A.; Ritchie, B.W. A farming crisis or a tourism disaster? An analysis of the foot and mouth disease in the UK. Curr. Issues Tour. 2003, 6, 150-171. [CrossRef]

28. Scott, N.; Laws, E.; Prideaux, B. Tourism crises and marketing recovery strategies. J. Travel Tour. Mark. 2008, 23, 1-13. [CrossRef]

29. Xu, J.; Grunewald, A. What have we learned? A critical review of tourism disaster management. J. China Tour. Res. 2009, 5, 102-130. [CrossRef]

30. De Sausmarez, N. Crisis management, tourism and sustainability: The role of indicators. J. Sustain. Tour. 2007, 15, 700-714. [CrossRef]

31. Laws, E.; Prideaux, B.; Chon, K. Crisis Management in Tourism; CABI: Wallingford, UK, 2007.

32. Anderson, B.A. Crisis management in the Australian tourism industries: Preparedness, personnel and postscript. Tour. Manag. 2006, 27, 1290-1297. [CrossRef] [PubMed]

33. Kang, P.; Lv, Y.; Deng, Q.; Liu, Y.; Zhang, Y.; Liu, X.; Zhang, L. Investigating Lushan earthquake victims' individual behavior response and rescue organization. Int. J. Environ. Res. Public Health 2017, 14, 1556. [CrossRef] [PubMed]

34. Lo, A.Y.; Cheung, L.T.O. Seismic risk perception in the aftermath of Wenchuan earthquakes in southwestern China. Nat. Hazards 2015, 78, 1979-1996. [CrossRef]

35. Mair, J.; Ritchie, B.W.; Walters, G. Towards a research agenda for post-disaster and post-crisis recovery strategies for tourist destinations: A narrative review. Curr. Issues Tour. 2016, 19, 1-24. [CrossRef]

36. The International Ecotourism Society (TIES). How Can the tourism Industries Improve Disaster Preparedness and Support Destinations' Recovery Efforts? 2013. Available online: http://www.ecotourism.org/news/howcan-tourism-industry-improve-disaster-preparedness-and-support-destinations-recovery-effort (accessed on 17 June 2020).

37. Hystad, P.W.; Keller, P.C. Towards a destination tourism disaster management framework: Long-term lessons from a forest fire disaster. Tour. Manag. 2008, 29, 151-162. [CrossRef]

38. Backer, E.; Ritchie, B.W. VFR travel: A viable market for tourism crisis and disaster recovery? Int. J. Tour. Res. 2017, 19, 400-411. [CrossRef]

39. Beirman, D. Restoring Tourism Destinations in Crisis: A Strategic Marketing Approach; CABI Publishing: Wallingford, UK, 2003.

40. Biran, A.; Liu, W.; Li, G.; Eichhorn, V. Consuming post-disaster destinations: The case of Sichuan, China. Ann. Tour. Res. 2014, 47,1-17. [CrossRef]

41. Okuyama, T. Analysis of optimal timing of tourism demand recovery policies from natural disaster using the contingent behavior method. Tour. Manag. 2018, 64, 37-54. [CrossRef] [PubMed]

42. Walters, G.; Clulow, V. The tourism market's response to the 2009 Black Saturday bushfires: The case of Gippsland. J. Travel Tour. Mark. 2010, 27, 844-857. [CrossRef]

43. Walters, G.; Mair, J. The effectiveness of post-disaster recovery marketing messages-The case of the 2009 Australian Bushfires. J. Travel Tour. Mark. 2012, 29, 87-103. [CrossRef]

44. Kaklauskas, A.; Amaratunga, D.; Haigh, R. Knowledge model for post-disaster management. Int. J. Strateg. Prop. Manag. 2009, 13, 117-128. [CrossRef]

45. Sydnor-Bousso, S.; Stafford, K.; Tews, M.; Adler, H. Toward a resilience model for the hospitality and tourism industry. J. Hum. Resour. Hosp. Tour. 2011, 10, 195-217. [CrossRef]

46. Ritchie, B.W. Tourism disaster planning and management: From response and recovery to reduction and readiness. Curr. Issues Tour. 2008, 11, 315-348. [CrossRef]

47. Coppola, D.P. Introduction to International Disaster Management, 3rd ed.; Elsevier Science \& Technology: Oxford, UK, 2015.

48. Brown, N.A.; Rovins, J.E.; Feldmann-Jensen, S.; Orchiston, C.; Johnston, D. Exploring disaster resilience within the hotel sector: A systematic review of literature. Int. J. Disaster Risk Reduct. 2017, 22, 362-370. [CrossRef] 
49. Filimonau, V.; de Coteau, D. Tourism resilience in the context of integrated destination and disaster management (DM2). Int. J. Tour. Res. 2020, 22, 202-222. [CrossRef]

50. Goldfine, E. Best Practices: The Use of Social Media throughout Emergency and Disaster Relief. Master's Thesis, American University, Washington, DC, USA, 2011.

51. Morakabati, Y.; Page, S.J.; Fletcher, J. Emergency management and tourism stakeholder responses to crises: A global survey. J. Travel Res. 2017, 56, 299-316. [CrossRef]

52. Kozak, M.; Crotts, J.C.; Law, R. The impact of the perception of risk on international travellers. Int. J. Tour. Res. 2007, 9, 233-242. [CrossRef]

53. Jiang, Y.; Ritchie, B.W. Disaster collaboration in tourism: Motives, impediments and success factors. J. Hosp. Tour. Manag. 2017, 31, 70-82. [CrossRef]

54. Mansfeld, Y. Cycles of war, terror and peace: Determinants and management of crisis and recovery of the Israeli tourism industries. J. Travel Res. 1999, 38, 30-36. [CrossRef]

55. Mojtahedi, M.; Oo, B.L. Critical attributes for proactive engagement of stakeholders in disaster risk management. Int. J. Disaster Risk Reduct. 2017, 21, 35-43. [CrossRef]

56. Haigh, R.; Amaratunga, D. An integrative review of the built environment discipline's role in the development of society's resilience to disasters. Int. J. Disaster Resil. Built Environ. 2010, 1, 11-24. [CrossRef]

57. Waligo, V.M.; Clarke, J.; Hawkins, R. Implementing sustainable tourism: A multi-stakeholder involvement management framework. Tour. Manag. 2013, 36, 342-353. [CrossRef]

58. De Brito, P.M.; Ferreira, A.M.; Costa, C. Tourism and third sector organisations-Strangers or partners? Tour. Plan. Dev. 2011, 8, 87-100. [CrossRef]

59. Cochrane, J. The sphere of tourism resilience. Tour. Recreat. Res. 2010, 35, 173-185. [CrossRef]

60. Jamal, T.; Budke, C. Tourism in a world with pandemics: Local-global responsibility and action. J. Tour. Futures 2020. [CrossRef]

61. Peleg, K.; Bodas, M.; Shenhar, G.; Adini, B. Wisdom of (using) the crowds: Enhancing disasters preparedness through public training in Light Search and Rescue. Int. J. Disaster Risk Reduct. 2018, 31, 750-757. [CrossRef]

62. Otley, D. The contingency theory of management accounting and control: 1980-2014. Manag. Account. Res. 2016, 31, 45-62. [CrossRef]

63. Appleby-Arnold, S.; Brockdorff, N.; Jakovljev, I.; Zdravković, S. Applying cultural values to encourage disaster preparedness: Lessons from a low-hazard country. Int. J. Disaster Risk Reduct. 2018, 31, 37-44. [CrossRef]

64. Ritchie, B.W. Crisis and Disaster Management for Tourism; Channel View Publications: Bristol, UK, 2009.

65. Oloruntoba, R.; Sridharan, R.; Davison, G. A proposed framework of key activities and processes in the preparedness and recovery phases of disaster management. Disasters 2018, 42, 541-570. [CrossRef] [PubMed]

66. Waugh, W.L.; Streib, G. Collaboration and leadership for effective emergency management. Public Adm. Rev. 2006, 66, 131-140. [CrossRef]

67. Granville, F.; Mehta, A.; Pike, S. Destinations, disasters and public relations: Stakeholder engagement in multi-phase disaster management. J. Hosp. Tour. Manag. 2016, 28, 73-79. [CrossRef]

68. Sawalha, I.H.S. Managing adversity: Understanding some dimensions of organisational resilience. Manag. Res. Rev. 2015, 38, 346-366. [CrossRef]

69. McComb, E.J.; Boyd, S.; Boluk, K. Stakeholder collaboration: A means to the success of rural tourism destinations? A critical evaluation of the existence of stakeholder collaboration within the Mournes, Northern Ireland. Tour. Hosp. Res. 2016, 17, 286-297. [CrossRef]

70. Hall, C.M.; Prayag, G.; Amore, A. Tourism and Resilience: Individual, Organisational and Destination Perspectives; Channel View Publications: Bristol, UK, 2018.

71. Saito, H.; Ruhanen, L. Power in tourism stakeholder collaborations: Power types and power holders. J. Hosp. Tour. Manag. 2017, 31, 189-196. [CrossRef]

72. Jopp, R.; DeLacy, T.; Mair, J. Developing a framework for regional destination adaptation to climate change. Curr. Issues Tour. 2010, 13, 591-605. [CrossRef]

73. Prideaux, B.; Coghlan, A.; Falco-Mammone, F. Post crisis recovery: The case of after Cyclone Larry. J. Travel Tour. Mark. 2007, 23, 163-174. [CrossRef]

74. Nozu, K. The impact of the Kumamoto earthquake to Kurokawa Onsen Hot Spring Resort, Minami-Oguni, Kumamoto. In Proceedings of the 11th Japan-Korea-China Joint Conference of Geography, New Otani Inn Sapporo, Sapporo, Japan, 13 September 2016. (In Japanese) 
75. Khazai, B.; Mahdavian, F.; Platt, S. Tourism Recovery Scorecard (TOURS)—Benchmarking and monitoring progress on disaster recovery in tourism destinations. Int. J. Disaster Risk Reduct. 2018, 27, 75-84. [CrossRef]

76. Hughey, K.F.D.; Becken, S. Value-engaged evaluation of a tourism-specific disaster management plan. Tour. Manag. Perspect. 2016, 19, 69-73. [CrossRef]

77. Orchiston, C.; Higham, J.E.S. Knowledge management and tourism recovery (de)marketing: The Christchurch earthquakes 2010-2011. Curr. Issues Tour. 2016, 19, 64-84. [CrossRef]

78. Hall, C.M. Crisis events in tourism: Subjects of crisis in tourism. Curr. Issues Tour. 2010, 13, 401-417. [CrossRef]

79. Novelli, M.; Gussing Burgess, L.; Jones, A.; Ritchie, B.W. 'No ebola ... still doomed'—The ebola-induced tourism crisis. Ann. Tour. Res. 2018, 70,76-87. [CrossRef]

80. Katsumata, K.; Ichiyanagi, M.; Ohzono, M.; Aoyama, H. The 2018 Hokkaido Eastern Iburi earthquake $\left(M_{\mathrm{JMA}}=6.7\right)$ was triggered by a strike-slip faulting in a stepover segment: Insights from the aftershock distribution and the focal mechanism solution of the main shock. Earth Planets Space 2019, 71. [CrossRef]

81. Hua, Y.; Zhao, D.; Xu, Y.; Wang, Z. Arc-arc collision caused the 2018 Eastern Iburi earthquake (M 6.7) in Hokkaido, Japan. Sci. Rep. 2019, 9, 13914. Available online: https://www.nature.com/articles/s41598-01950305-x (accessed on 17 June 2020).

82. Wakatsuki, Y.; Kobayashi, C. Earthquake buries homes under landslides in Hokkaido, Japan, 7 September 2018. Available online: https://edition.cnn.com/2018/09/05/world/japan-earthquake/index.html (accessed on 9 August 2020).

83. Serikawa, Y.; Miyajima, M.; Yoshida, M.; Matsuno, K. Inclination of houses induced by liquefaction in the 2018 Hokkaido Iburi-tobu earthquake, Japan. Geoenviron. Disasters 2019, 6, 14. [CrossRef]

84. Crotty, M. The Foundations of Social Research: Meaning and Perspective in the Research Process; Sage Publications Ltd.: London, UK, 1998.

85. Yin, R.K. Case Study Research: Design and Methods, 3rd ed.; Sage Publications Ltd.: Thousand Oaks, CA, USA, 2003.

86. Whiting, L.S. Semi-structured interviews: Guidance for novice researchers. Nurs. Stand. 2008, 22, 35. [CrossRef]

87. Jennings, G.R. Interviewing: A focus on qualitative techniques. In Tourism Research Methods—Integrating Theory with Practice; Ritchie, B.W., Burns, P., Palmer, C., Eds.; CABI Publishing: Wallingford, UK, 2005; pp. 99-117.

88. Silverman, D. Doing Qualitative Data: A Practical Handbook; Sage Publications: London, UK, 2000.

89. Braun, V.; Clarke, V. Using thematic analysis in psychology. Qual. Res. Psychol. 2006, 3, 77-101. [CrossRef]

90. Joffe, H. Thematic analysis. In Qualitative Research Methods in Mental Health and Psychotherapy; Harper, D., Thompson, A.R., Eds.; Wiley-Blackwell: London, UK, 2011; pp. 209-233.

91. Lieblich, A.; Tuval-Mashiach, R.; Zilber, T. Narrative Research: Reading, Analysis, and Interpretation; SAGE: Thousand Oaks, CA, USA, 1999.

92. Fereday, J.; Muir-Cochrane, E. Demonstrating rigor using thematic analysis: A hybrid approach of inductive and deductive coding and theme development. Int. J. Qual. Methods 2006, 5, 80-92. [CrossRef]

93. Tang, J.; Feng, J. Residents' disaster preparedness after the Meinong Taiwan Earthquake: A test of protection motivation theory. Int. J. Environ. Res. Public Health 2018, 15, 1434. [CrossRef] [PubMed]

94. Tucker, H.; Shelton, E.J.; Bae, H. Post-disaster tourism: Towards a tourism of transition. Tour. Stud. 2017, 17, 306-327. [CrossRef]

95. Kapucu, N. Interagency communication networks during emergencies: Boundary spanners in multiagency coordination. Am. Rev. Public Adm. 2006, 36, 207-225. [CrossRef]

96. Ketter, E. Destination image restoration on Facebook: The case study of Nepal's Gurkha Earthquake. J. Hosp. Tour. Manag. 2016, 28, 66-72. [CrossRef]

97. Avraham, E. Destination image repair during crisis: Attracting tourism during the Arab Spring uprisings. Tour. Manag. 2015, 47, 224-232. [CrossRef]

98. Ritchie, B.W.; Dorrell, H.; Miller, D.; Miller, G.A. Crisis communication and recovery for the tourism industries. J. Travel Tour. Mark. 2004, 15, 199-216. [CrossRef]

99. Nguyen, D.N.; Imamura, F.; Luchi, K. Disaster management in coastal tourism destinations: The case for transactive planning and social learning. Int. Rev. Spat. Plan. Sustain. Dev. 2016, 4, 3-17. [CrossRef]

100. Carter, S. Ryokan Etiquette-Customs \& Culture in Traditional Japanese Lodges. 2018. Available online: https://asocialnomad.com/japan/stay-in-a-ryokan-etiquette/ (accessed on 9 August 2020). 
101. Japan Ryokan and Hotel Association (JRHA). An Outline of the Japanese Ryokan for a Pleasant Stay. 2016. Available online: http://www.ryokan.or.jp/past/english/what/index.html (accessed on 9 August 2020).

102. Blackman, D.; Kennedy, M.; Ritchie, B. Knowledge management: The missing link in DMO crisis management? Curr. Issues Tour. 2011, 14, 337-354. [CrossRef]

103. Paraskevas, A.; Altinay, L.; McLean, J.; Cooper, C. Crisis knowledge in tourism: Types, flows and governance. Ann. Tour. Res. 2013, 41, 130-152. [CrossRef]

104. Coppola, D.P. Great East Japan Earthquake two-year update: Best practices, lessons learned, and implications for the post-2015 framework on disaster risk reduction. In Proceedings of the International Recovery Platform, Kobe, Japan, 21-22 January 2013.

105. Shimbun, Y. Quake-struck city overwhelmed by helpers. The Daily Yomiuri, 22 July 2007.

106. Hartman, S. Resilient tourism destinations? Governance implications of bringing theories or resilience and adaptive capacity to tourism practice. In Destination Resilience: Challenges and Opportunities for Destination Management and Governance; Innerhofer, E., Fontanari, M., Pechlaner, H., Eds.; Routledge: Oxon, UK, 2018; pp. 66-75.

107. Prideaux, B.; Laws, E.; Faulkner, B. Events in Indonesia: Exploring the limits to formal tourism trends forecasting methods in complex crisis situations. Tour. Manag. 2003, 24, 475-487. [CrossRef]

108. Sheppard, V.A. Resilience and destination governance. In Tourism and Resilience; Butler, R.W., Ed.; CABI: Oxfordshire, UK, 2017; pp. 53-68.

109. Becken, S.; Mahon, R.; Rennie, H.G.; Shakeela, A. The tourism disaster vulnerability framework: An application to tourism in small island destinations. Nat. Hazards 2014, 71, 955-972. [CrossRef]

110. Faulkner, B.; Vikulov, S. Katherine, washed out one day, back on track the next: A post-mortem of a tourism disaster. Tour. Manag. 2001, 22, 331-344. [CrossRef]

111. Pyke, J.; de Lacy, T.; Law, A.; Jiang, M. Building small destination resilience to the impact of bushfire: A case study. J. Hosp. Tour. Manag. 2016, 28, 49-58. [CrossRef]

112. Mao, C.K.; Ding, C.G.; Lee, H.Y. Post-SARS tourist arrival recovery patterns: An analysis based on a catastrophe theory. Tour. Manag. 2010, 31, 855-861. [CrossRef] [PubMed]

113. Blackman, D.; Ritchie, B.W. Tourism crisis management and organisational learning. J. Travel Tour. Mark. 2008, 23, 45-57. [CrossRef] 